Doi: HTTPS://DOI.ORG/10.23910/IJEP/2018.5.1.0239

\title{
Major Storage Rots of Apple: Occurrence and Distribution
}

\author{
Neelam Kumari ${ }^{*}$, J. N. Sharma ${ }^{1}$, Deepika Singh ${ }^{2}$ and Ashok K. Thakur ${ }^{3}$ \\ ${ }^{1}$ Dept. of Plant Pathology, ${ }^{2}$ Dept. of Fruit Science, ${ }^{3}$ Dept. of Seed Science and Technology, Dr. Y. S. Parmar University of \\ Horticulture and Forestry, Nauni, Solan, H.P. (173 230), India
}

\section{Corresponding Author}

Neelam Kumari

e-mail: neelkumari90@gmail.com

\author{
Article History \\ Article ID: IJEP239 \\ Received in $29^{\text {th }}$ October, 2017 \\ Received in revised form $20^{\text {th }}$ January, 2018 \\ Accepted in final form $10^{\text {th }}$ February, 2018
}

\section{Abstract}

Apple is one of most important fruit species worldwide. The wastage of apple during storage is often very serious. It may be brought about by various forms of physiological breakdown which are not of parasitic origin, but much is caused by fungal invasion resulting into decay, deterioration and rots. A number of fungal pathogens invading apple fruits during picking, grading, packing, transit, storage and marketing have been reported from many countries.

Keywords: Apple, fungal pathogens, rots

\section{Introduction}

Apple (Malusxdomestica Borkh.) is a member of Rosaceae family and considered one of the most economically important fruit tree of temperate zones. Apples are one of the most widely consumed fruits, due in part to their wide-range of beneficial effects on human health. A high intake of apples has been shown to prevent a variety of chronic diseases and reduce the risk of lung cancer, asthma, type-2 diabetes, thrombotic stroke, and ischemic heart disease (Hansen et al., 2009; Chai et al., 2011). These benefits are associated with the large content of structural cell walls and polysaccharide as well as various phytochemical antioxidants (Devic et al., 2010).

Fungal diseases play a major role in the wastage of long-stored apple. More than 90 fungal species have been described that cause decay of apples during storage in USA (Jones and Aldwinckle, 1991). The relative importance of each pathogen depends on climatic and storage conditions. Apple rot incidence may vary depending on cultivar (Sever et al., 2012; Weber, 2011) and harvest time (Borve et al., 2013). Losses due to post harvest disease are affected by a great number of factors including commodity type, post harvest environment (temperature, relative humidity, atmosphericcomposition, etc.), produce handling methods, post harvest hygiene, produce maturity and ripeness stage, cultivar susceptibility to post harvest diseases andtreatments used for disease control.

Among the different fungal pathogens, Alternaria alternata, Botrytis cinerea, Glomerella cingulata, Monilinia fructigena and Penicillium expansum are the dominant ones causing post harvest losses. Penicillium expansum Link causes the post harvest disease known as blue mould and is considered the most important disease of stored apples (Turechek, 2004). In most instances the post harvest pathogens gain entry to susceptible fruit tissues and cause infection via entry through fruit's surface wounds that are generated through the process of harvesting and post harvest handling. Some pathogens can also enter through natural openings like lenticels or decay may be initiated in the sinus between the calyx and core cavity (Spotts et al., 1988). Fruits, due to their low pH, higher moisture content and nutrient composition are very susceptible to attack by pathogenic fungi, which in addition to causing rots may also make them unfit for consumption by producing mycotoxins (Moss, 2002). The report of different storage rots reported from different parts of the world has been reviewed below.

\section{Blue Mould caused by Penicillium expansum}

Penicillium expansum Link, the cause of blue mould, is the most important postharvest pathogen of apples (Rosenberger, 1990). Postharvest losses in apple storages in the United States were estimated at more than $\$ 4.4$ million in 1992 (Rosenberger, 1997). P. expansum spores are abundant in soil (Jijakli and Lepoivre, 2004); therefore this pathogen can contaminate apples during the preharvest phase. In Europe, Penicillium rot is mostly caused by three Penicillium species, i.e. $P$. expansum, $P$. digitatum and $P$. solitum. Other species such as $P$. commune, $P$. verrucosum, $P$. chrysogenum or $P$. rugulosum only add a very low share to the complex 
of Penicillium rots. Penicillium rot is easily recognized by a relatively pale, soft lesion on which blue or green conidial pustules are produced.

Penicillium rot is one of the few postharvest diseases that can arise from infections of fruit during the storage phase. Despite its prevalence, losses in NW Europe attributed to this fungus are generally lower than 1\% (Palm and Kruse, 2005). $P$. expansum may become hyperparasitic, causing infections on fruit pre-infected by other pathogens and parasitizing their mycelium. During wet conditions at harvest, contamination of apple boxes with soil in the field may also provide a source of inoculum for the subsequent storage phase. Spores may survive from season to season on picking boxes, contaminated bins and on the walls of the storage rooms. Spores have also been reported to accumulate in postharvest drench solutions, in flotation tanks, and on packing lines (Morales et al., 2010). In warmer climates, such as Israel and southern France, $P$. expansum is reported as being the most severe storage pathogen, where losses may exceed 10\% (Amiri and Bompeix, 2010; Fallik et al., 1996). Penicillium griseofulvum was reported to cause blue mould on stored apples in Italy (Piedmont) (Spadaro et al., 2011). Apples harvested in 2010 were stored in a controlled atmosphere at a commercial Pennsylvania apple packing and storage facility, and were examined for occurrence of decay in May 2011. Several decayed apples from different cultivars, exhibiting blue mold symptoms with a sporulating fungus were collected (Maxin et al., 2012). Penicillium crustosum was reported to cause blue mould on stored apple fruits in Serbia (Vico et al., 2014).

\section{Brown Rot Caused by Monilinia fructigena}

Monilinia fructigena is one of several apothecial ascomycetes causing brown rot and blossom blight of stone fruit and pome fruit trees worldwide. Persoon (1796) was first to report Torula fructigena on pome and stone fruits, later transferred to Monilia fructigena (Persoon, 1801). Woronin (1900) published a detailed description of $M$. fructigena and $M$. cinerea causing brown rot of stone and pome fruits. Occurrence of brown rot (Sclerotinia fructicola) on pome and stone fruits from South America wa s reported by Soriano (1928). Moore (1950b) observed exceptional prevalence of brown rot (S. fructigena) on apples in Great Britain during 1949. In Tasmania, brown rot (S. fructicola) was stated to be responsible for loss of half the stone and pome fruits during seasons favourable for the disease (Wade, 1951). Wormald (1954) found discoloured lenticels spots on apples which enlarged in few days and showed typical brown fructification of $M$. fructigena. $M$. fructigena is the most thoroughly studied species in Europe, especially on apple and pear (Jones and Aldwinckle, 1990). M. fructigena is present throughout Europe, Asia (Near and Far East, India), North Africa, and some parts of South America (Batra, 1991). The production of $M$. fructigena spores on infected fruit is induced by light (Van Leeuwen and Van Kesteren, 1998). During storage in darkness, therefore, infections from one infected fruit to another wounded fruit are interrupted due to the absence of sporulation. M. fructigena is a wound pathogen on apple fruit (Xu and Robinson, 2000).

Brown rot caused by Monilinia fructigena is an important disease in apple orchards in Europe (Jijakli and Lepoivre, 2004). In the humid climate of NW Europe, the importance of $M$. fructigena is lower, $5 \%$ fruit loss from this fungus being regarded as high (Palm and Kruse, 2005). Preharvest infections commonly occur in fruit that have been attacked by biting insects such as larvae of codling moth (Cydia pomonella) and leaf rollers (e.g. Adoxophye sorana). In the field, fruit may become infected with $M$. fructigena during two time periods; in May when overwintering fruit mummies both in and under trees sporulate to release airborne conidia, and in June when infected fruit drop from the trees and then provide a source of spore inoculum for subsequent storage infections (Holb and Scherm, 2007). High fruit losses due to $M$. fructigena have been reported in Hungary, where up to $40 \%$ of apples were infected during the production phase in organically managed orchards. In comparison, orchards under integrated pest management suffered losses up to $10 \%$.

M. polystroma was reported for the first time to cause brown rot of apple fruits in Hungary (Petroczy and Palkovics, 2009). Monilinia fructicola is a causal agent of brown rot of stone fruits but may also affect pome fruits. $M$. fructicola is common in North America, Oceania, and South America as well as in Asia, but it is listed as a quarantine pathogen in Europe. Since its first discovery in Europe in 2001 (France), it has been reported in Spain, Slovenia, Italy, and Switzerland. Recently, the fungus was also detected in orchards of blackberries and plums in the State of Baden-Wurttemberg, Germany (Grabke et al., 2011). In storage, infected fruit become entirely colonized by $M$. fructigena. While the fruit remains firm and retains its original shape, it turns pitch-black in colour. At this late stage, brown rot may be confused with rubbery rot especially if an investigator is unfamiliar with the latter (Weber, 2012). For the first time, in Belarus the fungus Monilinia laxa on apple-tree was recorded (Lesik, 2013). Monilinia fructicola was reported for the first time to cause brown rot of apple fruits in Pennsylvania (Peter et al., 2015).

\section{Bitter Rot (Anthracnose) Caused by Colletotrichum spp.}

Fifty per cent fruits were rejected by Apple and Pear Assembly Department at Handerson in New Zealand on account of heavy incidence of Glomerella infection (Wilson, 1956). Investigating on the rotting of stored apples, Edney (1956) reported that losses due to G. perennans and G. album had reached $10 \%$. G. perennans and G. album were found to be the most important agents of apple rots from different parts of Finland (Talvia, 1960). Bitter rot of apple was reported to be of economic importance in New South Wales. Colletotrichum acutatum has a wide range of hosts; both trees and fruit are infected by this pathogen. In subtropical and tropical areas, C. acutatum as 
well as $C$. gloeosporioides are well known pathogens (Peres et al., 2005). C. acutatum has been reported as the most prevalent storage pathogen in Norway (Weber, 2009b; Borve et al., 2010). In the rest of NW Europe, the relative importance of this fungus in stored apples is low, although losses may be on the increase (Weber, 2009a). Fruit mummies and twig cankers cause infections on the maturing apples (Stensvand and Ren, 2010).

\section{Grey Mould Caused by Botrytis cinerea}

Wormald (1942) reported the stalk end rot of apples due to B. cinerea. Grey mould (Botrytis cinerea) is a common postharvest disease on apples worldwide (Rosenberger, 1990). This fungus has the ability to spread from decayed fruit to surrounding healthy fruit through fruit-to-fruit contact during storage. Because of this, significant losses as high as $20-60 \%$ are not uncommon after an extended period of storage, particularly on fruit that were not treated with fungicides prior to storage. Disease infection may occur in the field during harvest or earlier, but development usually occurs during the postharvest stage (Ten-Have et al., 1998). In countries with more continental and arid climates such as France, Belgium or Washington State (USA) and possibly as a result of different postharvest fungicide treatments, $B$. cinerea may contribute up to $28 \%$ to the total postharvest losses (Kader, 2002; Jijakli and Lepoivre, 2004; Kim and Xiao, 2008).

Botrytis rot is known as a nesting fungus because infections can spread within storage bins from apple to apple. Therefore, even low numbers of infected fruit may give rise to significant losses because fruit may rot in less than 3 weeks following initial contact (Jijakli and Lepoivre, 2004). In NW Europe, grey mould is a minor disease (Berrie, 2007; Weber, 2009b). Under favorable climatic conditions the fungus expands rapidly and may lead to devastating yield losses (Dean et al., 2012).

\section{Gloeosporium Rot or Bull's Eye Rot caused by Neofabraea} spp.

Bull's eye rot caused by Neofabraea spp. is an important postharvest disease of apple fruit worldwide. Four species of the genus are known to cause this disease among which Neofabraea alba is the main pathogen causing bull's eye rot in continental Europe. Bull's eye rot is more commonly seen on Golden Delicious, particularly on apples from orchards with perennial canker problems on trees. In NW Europe, the most common storage rots are caused by Neofabraea alba and its sister species Neofabraea perennans. Both species produce conidiomata on the surface of decayed areas of the fruit after prolonged storage. These are readily distinguished by microscopic features of their conidia which are asymmetrically elongated in N. perennans but strongly curved in N. alba. Both these pathogens are typically prevalent in mild humid climates with high precipitation during the summer months. $N$. perennans has been reported to cause significant storage losses all over the world. Cunnington (2004) revised Australian reports of $N$. malicorticis, concluding that all herbarium specimens collected after 1970 were, in fact, $N$. perennans. Gloeosporium rot has been reported in the USA on pears, an alternative host, where the ratio of $N$. alba to $N$. perenanns was 3:1 (Henriquez et al., 2004). It is the most common cause of storage rot in the Lower Elbe region of Northern Germany (Palm and Kruse, 2005). Neofabraea spp. was able to cause postharvest crop losses of $40 \%$ in fruit from organically managed orchards (Zimmer et al., 2011).

In the Pacific NW of the US, high apple losses were attributed to N. perenanns (Gariepy et al., 2005; Spotts et al., 2009), and this fungus was also reported in Brazil (Henriquez et al., 2006). Over-tree irrigation and late harvest resulted in higher bull's eye rot incidence than under-tree irrigation and early or midseason harvest (Henriquez et al., 2008). In Germany, long-term evaluations carried out from 1950 showed that the incidence of $N$. perennans and $N$. alba followed a North to South gradient; while the ratio of these two species was 3:1 in Northern Germany, the majority of fruit at Lake Constance in the deep south of Germany were infected by N. alba, a 1:1 ratio for these two rots being found in central regions of the country (Weber, 2009b). In Sweden, surveys on apple storage rots described $N$. alba as being the predominant rot (Tahir et al., 2009). In 550 samples of diseased fruits collected from nine cold storage rooms located in three regions of Poland, in 2011 and 2012, N. alba was detected as the predominant species causing bullss eye rot, occurring on average in $94 \%$ of the tested samples. Neofabraea perennans was found in a minority of apple samples, $N$. kienholzii was found only in two apple samples, while $N$. malicorticis was not detected in any sample tested (Michalecka et al., 2016). Typical symptoms of bull's eye rot were observed on 'Golden Delicious' apples in a local market in Belgrade, Serbia in March 2015 as circular, slightly sunken, light brown to dark brown lesions with a lighter brown to tan center and darker outer ring. Decayed tissue was firm (Vico et al., 2016).

\section{Blossom-end and Lenticel Rots Caused by Neonectria galligena}

Neonectria galligena is present in most orchards in NW Europe and is responsible for causing fruit tree canker. Infection of twigs and branches occurs all year round if wetness periods and temperatures are suitable. In freshly planted orchards the source of primary inoculum is often introduced with the trees directly from the nursery, or it invades as airborne ascospores from established neighboring orchards (Swinburne, 1975). Sporulation, spore dispersal and infections of $N$. galligena are directly linked with rainfall (McCracken et al., 2003). Fruit infections by $N$. galligena can be categorized into two groups, i.e. eye rot (blossom-end rot) and lenticel rot. The former develops from infections during blossom time, and the infection becomes clearly visible at the blossom end of the fruit by harvest time. Lenticel rot occurs during storage after a latency interval of several weeks as a result of infections 
originating from the field (Xu and Robinson, 2010). Globally, the presence of $N$. galligena in orchards has been correlated to months with more than $30 \%$ of the days having rainfall and an average temperature of $11-16{ }^{\circ} \mathrm{C}$ for more than $8 \mathrm{~h}$ per day (Beresford and Kim, 2011). Flower infections by $N$. ditissima commonly lead to a pre-harvest rot at the blossom end of the fruit, whereas infections of the growing fruit before harvest lead to a storage rot (Weber, 2014).

\section{Rubbery rot caused by Phacidiopycnis washingtonensis}

Phacidiopycnis washingtonensis has only recently been identified as the cause of a fruit rot in American (Kim and Xiao, 2006) and European (Weber, 2011) apple production. From 2003-2006, in approximately $25 \%$ of the surveyed orchards of Washington State (USA), 1-4\% of the apples were infected with P. washingtonensis (Kim and Xiao, 2006). Following 9 months storage up to $24 \%$ losses caused by $P$. washingtonensis were observed in 'Red Delicious' apples. Depending on the apple variety, invasion of $P$. washingtonensis occurred through stem end, calyx end, lenticels or wounds (Weber, 2012). First report of $P$. washingtonensis on apples in Europe was from the Lower Elbe region in Northern Germany, where fruit losses were below $1 \%$ in most orchards. Mummified fruits of 'Golden Hornet' crab apples commonly planted as pollinators were identified as a major source of inoculum; fruit mummies of dessert apple varieties such as 'Elstar' were also infected to a lesser degree (Weber, 2011). In Europe, cankers caused by $P$. washingtonensis have not yet been found.

Mycelium of $P$. washingtonensis may spread from an infected fruit to an adjacent intact fruit, causing clusters of rubbery rot. Rubbery rot is a highly variable disease, appearing as a very pale but firm rot when fruit are removed from long-term storage under an atmosphere of reduced oxygen content, but rapidly undergoing a browning if sufficient oxygen becomes available during subsequent cold storage or at room temperature (Weber, 2012). P. washingtonensis was reported to cause speck rot on stored pink lady apple fruits in Chile (Diaz et al., 2016).

\section{Mucor Soft Rot}

Mucor soft rot is an infrequently observed storage disease in NW Europe. However, Mucor spp. can spread in storage even at low temperatures $\left(<4{ }^{\circ} \mathrm{C}\right)$ and therefore, if present, they have potential to infect several adjacent apples. Fiftyone Anjou pear orchards were surveyed for Mucor spp. in the Naramata area of the Okanagan Valley of British Columbia by sampling the top $5 \mathrm{~cm}$ of soil beneath pear tree canopies within the orchards. Mucor spp. were found in 49 of the 51 orchards sampled (Sholberg and Owen, 1987). The most important fungus associated with Mucor soft rot is Mucor piriformis. Its sporangiospores are present in the soil and in organic matter (Guo and Michailides, 1997). Infection of apples is possible if spores are dislodged by rain or if fruit come into contact with soil. If soil on harvest bins is transferred into storage or into dump tanks, contamination of wounded fruit during storage is possible. In the western USA, high losses in apple and pear production have been reported from Mucor soft rot (Kader, 2002). Mucor rot was observed in February 2013 at a commercial packing facility in Pennsylvania, USA. Decay incidence was 15\% on Gala apples from bins removed directly from controlled atmosphere storage. Rot was evident mainly at the stem end and was light brown, watery, soft and covered with fuzzy mycelia (Li et al., 2014).

\section{Rhizopus Soft Rot}

Rhizopus stolonifer has a wide range of hosts and it is the causal agent of Rhizopus soft rot. This fungus has a high temperature optimum $\left(27^{\circ} \mathrm{C}\right)$, but because of its inability to grow or germinate below $4{ }^{\circ} \mathrm{C}$ (Pierson, 1966) Rhizopus is a minor storage rot pathogen in apples. Some susceptible hosts include Allium, Ananas, Brassica, Cucumis, Cucurbita, Fragaria, Lycopersicon, Phaseolus, Pisum and Solanum (Lunn, 1977). Rhizopus spores are common in orchards on debris and in the soil. Airborne spores are sometimes found in packhouses. Infected fruit are often covered by a coarse, grey, hairy mycelium that forms a mass of black sporangia at their tips. Infected fruit emit a sour odor. Spread of the fungus between adjacent fruit is possible where temperatures are $>4{ }^{\circ} \mathrm{C}$, e.g. during transport and retail phases (Kwon et al., 2011).

\section{Wet-core Rot Caused by Fusarium spp.}

Fusarium spp. have a wide host range but are a minor storage rot in apples. The disease incidence is generally below $1 \%$, although in some cases more than $5 \%$ have been reported (Weber, 2009b). Fusarium infections often begin as wet apple core rot, later spreading outwards to colonize the entire fruit. Wet growing conditions in the early season, when apple fruit point their blossom end upwards on the tree, enable sporecontaminated water to enter the flower, thereby initiating infections. Depending on the variety, this early infection of the apple core leads to an increased incidence of Fusarium rot in storage (Sorensen et al., 2009).

\section{Conclusion}

Storage rots due to fungi occur regularly during storage of apples and can cause severe yield and economic losses. Major storage rots of apple fruits are incited by Penicillium expansum, Alternaria alternata, Monilinia species, Trichothecium roseun, Colletotrichum sp. and Rhizopus stolonifer. Majority of these fungi are weak pathogens in that they can invade only damaged fruits; a few such as Colletotrichum are able to penetrate the skin of healthy fruit. Besides direct losses by these diseases, mycotoxins and secondary metabolites in fruits colonized by pathogens is a major dietary problem. To meet future need of increasing fruit consumption, the most feasible option is to check the microbial fruit spoilage.

\section{References}

Amiri, A., Bompeix, G., 2010. Control of Penicillium expansum 
with potassium phosphite and heat treatment. Crop Protection 30, 222-227.

Batra, L.R., 1991. World species of Monilinia (Fungi): their ecology, biosystematics and control. Mycologia Memoir 16, 246.

Batra, L.R., 1991. World species of Monilinia (Fungi): their ecology, biosystematics and control. Mycologia Memoir 16, 246.

Beresford, R.M., Kim, K.S., 2011. Identification of regional climatic conditions favourable for development of European canker of apple. Phytopathology 101, 135-46.

Berrie, A.M., 2007. Using rot risk assessment to minimize losses due to rots in cold stored apples. Novel approaches for the control of postharvest diseases and disorders. Cost action 924 Proceedings of the International Congress: Novel approaches for the Control of Postharvest Diseases and Disorders Bologna, Italy, 443-447.

Borve, J., Roen, D., Stensvand, A., 2010. Alternative means to reduce storage decay in organic apple production; time of harvest and calcium applications. IOBC/WPRS Bulletin 54, 61-64.

Borve, J., Roen, D., Stensvand, A., 2013. Harvest time influences incidence of storage diseases and fruit quality in organically grown 'Aroma' apples. European Journal of Horticultural Science 78, 232-238.

Chai, S.C.S., Hooshmand, R.L., Saadat, B.H., Arjmandi, 2011. Daily apple consumption promotes cardiovascular health in postmenopausal women. Journal of the Federation of American Societies for Experimental Biology 25, 971-981.

Cunnington, J.H., 2004. Three Neofabraea species on pome fruit in Australia. Australasian Plant Pathology 33, 453-454.

Dean, R., Van Kan, J.A.L., Pretorius, Z.A., Hammond-Kosack, K.E., Di Pietro, A., Spanu, P.D., Rudd, J.J., Dickman, M., Kahmann, R., Ellis, J., Foster, G.D., 2012. The Top 10 fungal pathogens in molecular plant pathology. Mol. Plant Pathol. 13, 414-430.

Devic, E.S., Guyot, J.D., Daudin, Bonazzi, C., 2010. Kinetics of polyphenol losses during soaking and drying of cider apples. Food and Bioprocess Technology 3, 867-877.

Diaz, G.A., Zoffoli, J.P., Lolas, M., Blanco, A., Latorre, B.A., Ferrada, E.E., Elfar, K., Naranjo P., 2016. Occurrence of Phacidiopycnis washingtonensis Causing speck rot on stored pink lady apple fruit in chile. Plant Disease 100, 211.

Edney, K.L., 1956. The rotting of apples by Gloeosporium perennans Zeller and Childs. Annals Applied Biology, Warwick 44, 113-128.

Fallik, E., Grinberg, S., Gambourg, M., Klein, J., Lurie, S., 1996. Pre storage heat treatment reduces pathogenicity of Penicillium expansum in apple fruit. Plant Pathology 45, 92-97.

Gariepy, T.D., Rahe, J.E., Levesque, C.A., Spotts, R.A.,
Sugar, D.L., Henriquez, J.L., 2005. Neofabraea species associated with bull's eye rot and cankers of apple and pear in the Pacific Northwest. Canadian Journal of Plant Pathology 27, 118-124.

Grabke, A., Hu, M.J., Luo, C.X., 2011. First Report of Brown Rot of Apple Caused by Monilinia fructicola in Germany. Plant Disease 95, 772.

Guo, L.Y., Michailides, T.J., 1997. Survival of Mucor piriformis in soil of apple orchards in California. Phytopathology 87, 37.

Hansen, L.H., Vehof, L.O., Dragsted, A., Olsen, J., Christensen, K., Overvad, A., 2009. Fruit and vegetable intake and serum cholesterol levels: a cross sectional study in the diet, cancer and health cohort. Journal of Horticultural Science \& Biotechnology, Isafruit Special Issue, 42-46.

Hennecke, C., Koepcke, D., Dierend, W., 2008. Dynamische Absenkung des Sauerstoffgehaltesbei der Lagerung von Apfeln. Erwerbs-Obstbau 50, 19-29.

Henriquez, J.L., Sugar, D., Spotts, R.A., 2004. Etiology of bull's eye rot of pear caused by Neofabraea spp. in Oregon, Washington, and California. Plant Disease 88, 1134-1138.

Henriquez, J.L., Sugar, D., Spotts, R.A., 2006. Induction of cankers on pear tree branches by Neofabraea alba and $N$. perennans, and fungicide effects on conidial production on cankers. Plant Disease 90, 481-486.

Henriquez, J.L., Sugar, D., Spotts, R.A., 2008. Effects of environmental factors and cultural practices on bull's eye rot of pear. Plant Disease 92, 421-424.

Holb, I.J., Scherm, H., 2007. Temporal dynamics of brown rot in different apple management systems and importance of dropped fruit for disease development. Phytopathology 97, 1104-1111.

Jijakli, M., Lepoivre, P., 2004. State of the art and challenges of postharvest disease management in apples. In Mukerji, K.G. (Ed.), Fruit and Vegetable Diseases Vol. 1, Kluwer, Dordrecht, 59-94.

Jones, A.L., Aldwinckle, H.S., 1990. Brown rot diseases. Compendium of Apple and Pear Diseases. American Phytopathology Society, 1-100.

Jones, A.L., Aldwinckle, H.S., 1991. Compendium of apple and pear diseases. The American Phytopathological Society, St. Paul, MN. USA.

Kader, A.A., 2002. Postharvest Technology of Horticultural Crops. Agriculture and Natural Resources, University of California, 338.

Kim, Y.K., Xiao, C.L., 2006. A postharvest fruit rot in apple caused by Phacidiopycnis washingtonensis. Plant Disease 90, 1376-1381.

Kim, Y.K., Xiao, C.L., 2008. Distribution and incidence of Sphaeropsis rot in apple in Washington State. Plant Disease 92, 940-946.

Kwon, J.H., Kim, J., Kim, W.I., 2011. First report of Rhizopus oryzae as a postharvest pathogen of apple in Korea. 
Mycobiology 39, 140-142.

Lesik, K., 2013. Monilinia Species causing fruit brown rot, blossom and twig blight in apple orchards in belarus. Proceedings of the Latvian Academy of Sciences. Section B 67, 192-194.

Li, J., Gaskins, V.L., Yan, H.J., Luo, Y.G., Jurick, W.M., 2014. First report of Mucor rot on stored Gala apple fruit caused by Mucor piriformis in Pennsylvania. Plant Disease 98, 1157.

Lunn, J.A., 1977. Rhizopus stolonifer. CMI Descriptions of Fungi and Bacteria, 524.

Maxin, P., Weber, R.W.S., Pederson, H.L., Williams, M., 2012. Hot-water dipping of apples to control Penicillium expansum, Neonectria galligena and Botrytis cinerea: Effects of Temperature on Spore Germination and Fruit Rots. Europ. Journal of Horticultural Science 77, 1-9.

McCracken, A.R., Berrie, A., Barbara, D.J., Locke, T., Cooke, L.R., Phelps, K., Swinburne, T.R., Brown, A.E., Ellerker, B., Langrell, S.R.H., 2003. Relative significance of nursery infections and orchard inoculum in the development and spread of apple canker (Nectria galligena) in young orchards. Plant Pathology 52, 553-566.

Michalecka, M., Bryk, H., Poniatowska, A., Puławska, J., 2016. Identification of Neofabraea species causing bull's eye rot of apple in Poland and their direct detection in apple fruit using multiplex PCR. Plant Pathol 65, 643-654.

Moore, M.H., 1950b. Brown rot of apples: fungicide trials and studies of the relative importance of different woundagents. Journal of Horticultural Science 25, 225-234.

Morales, H., Marin, S., Ramos, A.J., Sanchis, V., 2010. Influence of postharvest technologies applied during cold storage of apples on Penicillium expansum growth and patulin accumulation: a review. Food Control 21, 953-962.

Moss, M.O., 2002. Mycotoxin review. 1. Aspergillus and Penicillium. Mycologist 16, 116-119.

Palm, G., Kruse, P., 2005. Maßnahmenzur Verminderung der Verlustedurch Fruchtfaunisbei Apfel. Mitteilungen des Obstbauversuchsringes des Alten Landes 60, 46-52.

Peres, N.A., Timmer, L.W., Adaskaveg, J.E., Correll, J.C., 2005. Lifestyles of Colletotrichum acutatum. Plant Disease 89, 784-796.

Persoon, C.H., 1796. Observationes mycologicae 1, 1-116.

Persoon, C.H., 1801. Pars Prima. Syn. Meth. Fung. Henricum Dieterich, Gottingae 1801, 1-240.

Peter, K.A., Gaskins, V.L., Lehman, B., Jurick, W.M., 2015. First report of brown rot on apple fruit caused by Monilinia fructicola in Pennsylvania. Plant Disease 99, 1179.

Petroczy, M., Palkovics, L., 2009. First report of Monilia polystroma on apple in Hungary. European Journal of Plant Pathology 125, 343-347.

Pierson, C.F., 1966. Effect of temperature on the growth of Rhizopus stolonifer on peaches and agar. Phytopathology 56, 276-278.

Rosenberger, D.A., 1990. Blue mould. Pages $54-55$ in: A Compendium of Apple and Pear Diseases. Jones, A.L.,
Aldwinckle, H.S. (Eds.) American Phytopathological Society, St. Paul, MN.

Rosenberger, D.A., 1997. Recent research and changing options for controlling postharvest decays of apples. Pages 42-53. in: Proc. Harvesting, Handling, and Storage Workshop, Cornell Univ., Ithaca, 14 ${ }^{\text {th }}$ August 1997. Northeast Regional Agric. Engin. Serv. Publ. NRAES-112, Cornell University, Ithaca.

Sever, Z., Ivic, D., Kos, T., Milicevic, T., 2012. Fusarium rot in stored apples in Croatia. Arh Hig Rada Toksikol 63, 463-470.

Sholberg, P.L., Owen, G.R., 1987. Incidence of pathogenic Mucor spp. in Anjou pear orchard soils in the Okanagan Valley of British Columbia. Canadian Plant Disease Survey 6, 9-10.

Sorensen, J.L., Phipps, R.K., Nielsen, K.F., Schroers, H.J., Frank, J., Thrane, U., 2009. Analysis of Fusarium avenaceum metabolites produced during wet apple core rot. Journal of Agricultural and Food Chemistry 57, 1632-1639.

Soriano, S., 1928. Mycological notes on the cultivation in artificial media of some fungi parasitic on plants. Rev. Fac. Agron. B. Aires. 6, 89-114.

Spadaro, D., Pellegrino, C., Garibaldi, A., Gullino, M.L., 2011. Development of SCAR primers for the detection of Cadophoraluteo-olivacea on kiwifruit and pome fruit and of Cadophora malorum on pome fruit. Phytopathologia Mediterranea 50, 430-441.

Spotts, R.A., Holmes, J.R., Washington, W.S., 1988. Factors effecting wet core rot of apples. Aus. Plant Pathol. 14, 53-57.

Spotts, R.A., Seifert, K.A., Wallis, K.M., Sugar, D., Xiao, C.L., Serdani, M., Henriquez, J.L., 2009. Description of Cryptosporiopsis kienholzii and species profiles of Neofabraea in major pome fruit growing districts in the Pacific Northwest USA. Mycological Research 113, 1301-1311.

Stensvand, A., Ren, D., 2010. Sources of inoculum for Colletotrichum acutatum in cherry and apple. IOBC/ WPRS Bulletin 54, 65-67.

Swinburne, T.R., 1975. European canker of apple (Nectria galligena). Review of Plant Pathology 54, 787-799.

Tahir Ibrahim, I., Johansson, E., Olsson Marie, E., 2009. Improvement of Apple Quality and Storability by a Combination of Heat Treatment and Controlled Atmosphere Storage. HortScience 44, 1648-1654.

Talvia, P., 1960. Various species of Gloeosporium in stored apples in Finland. J. Sci. Agric. Soc. Finland 32, 239-246.

Ten-Have, A., Mulder, W., Visser, J., Van-Kan, J., 1998. The endopolygalactronase gene Bcpyl is required for full virulence of Botrytis cinerea. Mol. Plant microbe Intract. 11, 1009-1016.

Turechek, W.W., 2004. Apple diseases and their management. Diseases of fruits and vegetables 1, 1-108.

Van Leeuwen, G.C.M., Van Kesteren, H.A., 1998. Delineation of 
the three brown rot fungi of fruit crops (Monilinia spp.) on the basis of quantitative characteristics. Canadian Journal of Botany 76, 2042-2050.

Vico, I., Duduk, N., Vasic M, Nikolic, M., 2014. Identification of Penicillium expansum causing postharvest blue mould decay of apple fruits. Pestic. Phytomed 29, 257-266.

Vico, I., Duduk, N., Vasic, M., Zebeljan, A., Radivojevic, D., 2016. Bull's eye rot of apple fruit caused by Neofabraea alba. Acta Horticulturae 1139, 733-738.

Wade, G.C., 1951. Progress report of brown rot of apricot investigations. Tasm. J. Agri. 22, 258-256.

Weber, R.W.S., 2009a. Betrachtungmoglicher Auswirkungen des Klimawandels auf Schadpilzeim Obstbau am Beispiel von Fruchtfauleerregern an Apfeln. Erwerbs-Obstbau $51,115-120$.

Weber, R.W.S., 2009b. Lagerfaulen an Apfeln: Aktuellesaus Europa. Mitteilungen des Obstbauversuchsringes des Alten Landes 64, 227-231.

Weber, R.W.S., 2011. Phacidiopycnis washingtonensis, cause of a new storage rot of apples in Northern Europe. Journal of Phytopathology 159, 682-686.

Weber, R.W.S., 2012. Die Gummifaule, eineneuepilzliche Lagerfaule des Apfels in Europa. Mitteilungen des Obstbauversuchsringes des AltenLandes 67, 86-91.

Weber, R.W.S., 2014. Biology and control of the apple canker fungus Neonectria ditissima (syn. N. galligena) from a Northwestern European perspective. Erwerbs-Obstbau $56,95-107$.

Wilson, G.J., 1956. Glomerella infection in Auckland district. Orchardist N Z 29, 27-31.

Wormald, H., 1942. The grey mould of fruit and hops; weeds as possible sources of infection. Rep. E. Malling Res. Stn. 1941, 44-47.

Wormald, H., 1954. The brown rot diseases of fruit trees. Ministry of Agriculture and Fisheries. Technical Bulletin No. 3, 1-137.

Woronin, M., 1990. Uber Sclerotiniacinerea und Sclerotinia fructigena. Mem. Acad. Sci. St. Petersb. VIIle ser., 10, Phys. Math., 1-38.

Xu, X.M., Robinson, J.D., 2000. Epidemiology of brown rot (Monilinia fructigena) on apple: infection of fruits by conidia. Plant Pathology 49, 201-206.

Xu, X.M., Robinson, J.D., 2010. Effects of fruit maturity and wetness on the infection of apple fruit by Neonectria galligena. Plant Pathology 59, 542-547.

Zimmer, J., Benduhn, B., Mayr, U., Kunz, S., Rank, H., 2011. Erarbeitungeiner Strategiezur Reduzierung des Kupfereinsatzesbei der Apfelschorfbekamp fungi möko logischen Obstbau. (organiceprints ID: 19277). 